Article

\title{
Empirical Study towards Corporate Social Responsibility Practices and Company Financial Performance. Evidence for Companies Listed on the Bucharest Stock Exchange
}

\author{
Liliana Nicoleta Simionescu * (1) and Dalina Dumitrescu \\ Department of Finance, The Bucharest University of Economic Studies, 6 Piata Romana, 010374 Bucharest, \\ Romania; dalina.dumitrescu@fin.ase.ro \\ * Correspondence: liliana.simionescu@fin.ase.ro; Tel.: +40-744-398-176
}

Received: 19 July 2018; Accepted: 28 August 2018; Published: 3 September 2018

\begin{abstract}
The present paper empirically examines the relation between corporate social responsibility (CSR) practices and company financial performance (CFP) for firms listed on the Bucharest Stock Exchange. Likewise, the paper analyzes the CSR policies adopted by the companies as CSR practices towards six types of stakeholders that influence the CFP. Using principal component analysis, we developed a CSR index and several specific indices for CSR practices. By estimating cross-sectional regression models, our study provides support for a positive link between CSR and CFP, when companies implement CSR policies regarding employees, environmental protection, and ethics as social practices. Further, empirical findings show that companies responsive to the CSR concept and those considering international standards and regulations for quality products and services in their business strategy enhance CFP.
\end{abstract}

Keywords: corporate social responsibility; company financial performance; Romania; principal component analysis; cross-sectional regression models

\section{Introduction}

During recent years, corporate social responsibility (CSR) has become a widely and frequently debated topic in the academic community given the effects that business-environment activities have on employees, clients, authorities, society, business partners, investors, environment, and local communities [1]. In this sense, an ever-heftier number of companies aim at including CSR practices in their business strategies through sustained efforts. Companies adopt these practices voluntarily [2]. Companies are more and more aware of the fact that they must accept the responsibility regarding the impact of their business activity on all the stakeholders and support, through voluntary actions, the communities where they perform their economic activity [3]. CSR has existed in business practices for a long time. However, only a handful of companies have chosen to play a more active role in promoting the CSR policies. Such social responsibility practices are adopted because of either the pressure exercised by the government and society, or the benefits such practices have on the companies. Thus, social responsibility encourages companies to balance social responsibilities and environmental responsibilities with profit. Consequently, profit maximization or a continuous market-share increase should be the main objective for companies [4]. As businesses evolve, others objectives keep on adding as well, to an ever-bigger extent, so as to lead to synergic effects. These objectives must also consider the effects of business decisions on stakeholders. The development of the relationship between companies, the state, and society, over the past two decades, has led to an increase in the pressure on the business environment to make serious efforts to adopt and/or implement a wide range of CSR activities [5]. 
The ever-growing interest in CSR has drawn the attention of researchers and of the business environment on its legitimacy and its effects on company performance. Stakeholders play an important role in the financial performance of a company [6]. Thus, companies have adopted CSR practices in nontax fields such as human rights, environmental protection, corporate contributions (sponsorships and philanthropic actions), local-community development, and workplace-related matters. Companies implementing CSR activities in their business strategy can strengthen clients' loyalty [7], boost the company image and reputation [8,9], offer a competitive advantage [10], and attract and maintain the best employees [11]. Thus, companies adopting CSR practices can increase their financial performance. Companies implementing CSR in their business strategy adopt different social-responsibility practices. Several factors influencing the decision-making of the companies in adopting CSR activities are as follows: company size, organizational culture, the stakeholders' requirements, the labor market conditions, the industry in which the company operates, and the geographical area in which the company performs its economic activity [12-15]. The specialized literature also highlights the fact that CSR practices create additional costs for companies [16]. Unless such costs produce positive elements reflected in added company performance, such costs can affect the company results, which, in turn, may lead to a competitive disadvantage [17]. Friedman [4] underlined that the only responsibility a company has is to increase shareholder wealth. Friedman followers argued that CSR only brings additional costs to the company, thus reducing shareholder wealth [18]. Moreover, Winchester, et al. [19] found not only a negative relation between CSR and company financial performance (CFP) but also showed that companies adopt CSR practices whenever their brand or image is affected. Researchers found a negative relation between CSR and CFP when market base measures were included in their analyses [20], different control variables, as well as multiple-industries inclusion in the regression models [21]. Hence, CSR activities continue to elicit doubts as to whether such initiatives may lead to an improved company performance and whether they are a source of sustainable competitive advantage.

Most studies analyzing the relationship between CSR and company performance are performed in the case of developed countries and very few studies were performed in the case of developing or emerging countries. CSR in developing countries or emerging countries is understood as a philanthropic, public-relation, or marketing activity [22]. Corporative responsibility should be explicitly understood as a responsibility toward stakeholders. The problem of understanding CSR was identified by Freeman et al. [23] as being nothing else than efficient stakeholder management. In another conception, CSR regards those practices meant to alleviate stakeholder suffering caused by capitalism and left unresolved by governments [24].

Pan et al. [25] analyzed the relation between CSR and CFP on listed Chinese mineral companies from 2010 to 2013. Their results showed a positive and significant relation between CSR and CFP. Moreover, the authors' empirical study demonstrates that CSR practices toward shareholders, employees, the environment, suppliers, customers, and consumers increase CFP. Similarly, Chou et al. [26] found that listed companies from Taiwan adopting CSR practices enhanced their financial performance. The study of Senyigit and Shuaibu [27] on emerging countries showed mixed results. The authors examined listed banks from Turkey and Nigeria over the period from 2009 until 2014. Their results showed that CSR activities positively influenced listed banks in Nigeria, whereas in the case of Turkey the results did not hold.

Romania is a developing country [28] and it is included in the Secondary Emerging Market category [29]. Therefore, the current paper aims at identifying existing CSR practices and at empirically investigating the relation between CSR and CFP for firms listed on the Bucharest Stock Exchange (BSE) implementing such activities. CSR practices are already being implemented by a vast number of companies listed on the BSE, in various fields of economic activity. A part of these companies reports their CSR activities. We notice the existence of various CSR indices worldwide, such as the Dow Jones Sustainability Index series (DJSI), Calvert Social Index (CSI), FTSE4GOOD series, FTSE Johannesburg Stock Exchange Socially Responsible Index (JSE SRI), Sao Paolo Stock Exchange 
Corporate Sustainability Index (ISE), and KLD Global Sustainability Index Series (GSI). Nevertheless, as the companies listed in Romania are not bound to report CSR practices, and a CSR index is not reported at BSE, few papers have been able, so far, to precisely identify what this concept represents in the Romanian context and whether companies truly increase their financial performance by implementing these activities. Thus, the present paper in this respect is found to be insufficient research for the companies listed on the BSE regarding the relationship between CSR and company performance. Unlike other studies that analyzed this relationship on the case of Romania, where CSR was considered a dummy variable or a financial indicator as proxy variable, this study aims to develop a CSR index in order to examine whether these practices influence CFP. Moreover, for a comprehensive understanding, we developed not only a CSR index for companies listed on BSE, but we also developed specific indices for CSR policies based on practices adopted by the companies in relation to the company stakeholders. The study of the CSR-CFP relation has shifted toward analyzing the aspects that link these two concepts [30]. Our study shows that CSR practices with employees, environmental protection, and ethics enhance CFP.

The rest of the paper is organized as follows: Section 2 approaches the literature review, Section 3 describes the paper methodology, Section 4 discusses the empirical results, and the final section presents the paper conclusions.

\section{Literature Review and Hypotheses Development}

Corporate social responsibility is defined as the actions carried out by companies positively influencing society where they perform their economic activity [31]. CSR is a concept encouraging certain volunteering-based social activities or responsibilities towards the stakeholders of a company [8]. Such social activities undertaken by the companies are not directly linked to the business, but their effects have an indirect positive impact on company activity [32-34]. For instance, as a result of these social activities, the stakeholders can have a positive image of the company practicing such social activities, the morale of the employees working in such a company can be amplified, and all these can generate a positive effect on company productivity [32,35]. Moreover, companies implementing CSR activities increase not just their performance but the firm value as well $[36,37]$. Although various definitions have been put forward for the CSR concept, there is still no unanimously accepted definition [38]. Consequently, some researchers question the applicability, standards, and principles of the CSR, as well as its legitimacy, since no clear CSR limits exist [39,40]. The numberless attempts at precisely defining the CSR field has led to increased confusion in the field [41]. CSR study is difficult in the absence of a well-defined analytical framework [42]. The lack of an unanimously accepted definition of the concept of CSR and of its norms, regulations, and study methodologies has led to different results as regards to the analysis of the relationship between CSR and CFP.

We say that CSR is a commitment undertaken voluntarily by companies in order to respond to the expectations coming from the employees, clients, environment, local communities, as well as to the commitment to support education and healthcare performance, aiming at increasing the financial performance in the long run, but also sustainable business development. Thus, the effects of CSR activities determine the investment strategy accruing to projects such as the CSR.

As mentioned previously, the paper objective is to analyze the relation between CSR and CFP. Furthermore, the study aims at thoroughly researching the relation between policies adopted by companies in the form of CSR practices and CFP. In this paper, we will refer to a policy as a set of practices adopted by the companies toward stakeholders in order to reach their long-term goals. Thus, this paper aims at investigating the effects of the CSR policies adopted by the companies as practices from a multidimensional perspective, namely focusing on the six types of stakeholders (four direct stakeholders and two indirect stakeholders). The direct stakeholders are employees, clients, the environment, and local communities. The CSR practices of companies completing government activity in activity areas related to education (hereinafter referred to as education-related CSR practices) 
and to healthcare (hereinafter referred to as healthcare-related CSR practices) are in this paper identified and considered to be indirect stakeholders, being important in a wider concept to CSR activity, alongside the four previously mentioned stakeholders. Healthcare- and education-related CSR practices strengthen the commitment of employees and local communities as they start to identify themselves with the company [43]. Therefore, according to Dumitrescu and Simionescu [43] this leads to a higher performance of the companies. The understanding and development of these six types of stakeholders make up a complete CSR matrix, resulting in increased competiveness [44] and sustainable company development in the society where it performs its activity [45]. A comparison is therefore required of the effects various CSR policies have in relation to the six types of stakeholders on company performance by establishing some connections between the CSR and the CFP for the companies making up the basis of this scientific paper.

Previous studies have shown the existence of a positive relation between CSR and CFP [15,46-52], as well as a negative relation or the lack of a statistically significant relation $[53,54]$. Thus, the following hypothesis is developed:

Hypothesis 1 (H1). There is a positive relation between CSR and CFP in the case of companies listed on the $B S E$, ceteris paribus.

Numerous researchers have considered, along the years, many elements of the CSR concept [55-61]. In their studies, these authors examine CSR activities regarding their impact on company employees. These study results have shown that the companies performing CSR activities relate better to the employees, clients, shareholders, environment, suppliers, and the local communities. According to the same authors, companies create added value through an appropriate communication and understanding of the company stakeholders' requests. From country to country, the pattern of communication and performance of the CSR-type activities is certainly different in terms of economic development, culture, religion, traditions, government actions, and the severity of the social and environmental problems the country faces [62,63].

The employees, the human element of a company, are an important resource in implementing the company strategy [64]. Volunteering Australia [65] emphasized that almost half of the world's largest companies believe that motivating employees is key to the CSR actions and their involvement [65]. Each employee in a company is not only an important resource to it, but is also considered a valuable player in the company. The employee value resides in their competence, in the absence of which the company would lack both the performance and the competitive advantage [66]. Davenport [67], Graves and Waddock [68], and Wood [69] consider the following to be CSR initiatives for and related to the employees or practices ensuring an agreeable working environment: responsible human-resources management (nondiscrimination at the workplace, promotion at the workplace), granting fair rewards and a correct employee waging system, open and flexible communication with the employees, and investment by the company in the employees' personal development.

Companies can attain a competitive advantage through strategies such as cost leadership, marketing differentiation, and innovative differentiation [13]. These are strategies used by corporations in order to improve their employees' commitment, and to include factors such as closer community, better collaboration, employee loyalty and dedication to the company, and more active involvement initiatives at the workplace. Furthermore, the costs the companies bear with CSR practices are overcompensated by the benefits they gain as an effect of boosted morale and increased productivity of the company employees [70-72]. Post et al. [73] recommend that companies should develop the employees' human capital, this being a specific action related to the competitive advantage. Thereafter, the same authors show that dedicated employees can help reach the company objectives. Managers and employees determine the quality of the work reflected in the company product and services, which further expresses the company competitive advantage [74]. Thus, this paper develops the following hypothesis: 
Hypothesis 2 (H2). Employee-related CSR practices have a positive influence on the CFP.

Clients are the most important stakeholder for the company, and they are perceived as a main driver for corporations to adopt CSR practices. Client satisfaction can be defined as a general evaluation regarding the purchase experience and the consumer's total consumption, over time, of a certain product or service [9,75]. Fornell et al. [76] stated that client satisfaction is a determining factor of company profitability in the long run, and of its market value [77]. These reasons are considered to be driving factors for companies implementing and applying CSR practices. Davenport [67] and Wood [69] developed theoretical frameworks regarding the CSR activities oriented towards the concerns of the client, such as: respecting consumers' rights, providing quality products and services, and providing correct information regarding the products and services offered by companies. The specialized literature shows that the CSR actions carried out by companies manipulate market value insofar as client satisfaction is concerned [78-80]. The same authors mentioned, however, that some aspects of CSR practices have an innovative character, and contribute to enhancing the quality of the products and/or services offered by the companies through CSR activities, which increase client satisfaction. The studies carried out by Lee and Heo [81] showed that client satisfaction is influenced by CSR practices, thus positively influencing CFP. Therefore, based on the specialized literature, the following hypothesis is developed for companies listed on the BSE:

Hypothesis 3 (H3). Client-related CSR practices have a positive influence on the CFP.

Environmental protection is considered to be of public interest [82]. Mishra and Suar [83] highlighted that performance in the field of environmental responsibility activities is boosted by the improvement of three aspects. These aspects regard the use of recycled materials and other resource-saving programs in product technology; technological processes such as efficient-production systems; and management systems such as continuous employee-training programs and environment auditors. The researchers' evidence suggested that proactive environmental management increases the market value of a company, as well as its reputation and financial performance [84,85].

The organization is responsible for protecting the environment. Many organizations do this voluntarily. Therefore, through environment-protection practices, companies must minimize the actions that might harm natural resources. Moreover, the efficient management of pollutant emission and waste disposal needs to be correlated to a maximization of company resource productivity and efficiency [67,69].

Previous research that focused on studying the relation between environment performance and the CFP highlights important arguments regarding the result of such a relation. Elsayed and Paton [86] emphasized that the "faith of the win-win strategy followers" $[87,88]$ is that the improvement or protection of the environment can benefit not only the company interest, but also the company mutual aid at a wider level" [86]. Nevertheless, Palme, et al. [89], and Walley and Whitehead [90] argued that companies must make a compromise (at least, in the short term) between environmental performance and the CFP. McWilliams and Siegel [3] support the argument of Elsayed and Paton [86], according to which the "optimal level of the CSR investments for a company can be evaluated in the same way the other investments are evaluated, by taking into account the marginal costs and benefits" [86]. Studies, however, showed that a positive relation exists between environmental CSR practices and CFP $[3,86]$. Consequently, the following hypothesis is developed:

Hypothesis 4 (H4). Environment-related CSR practices positively influence the CFP.

The companies take the opinion of the public at large into consideration when evaluating their social activities. The community is one of the most important CSR activities [2]. The stakeholders' education, healthcare, housing, and security are CSR activities related to the local community. Unlike the categories of stakeholders consisting of employees, clients, and the environment, local communities 
are a more important category for the companies' stakeholders, since they consist of members of the public at large, of the society where the company performs its economic activity. Lesser [91] showed that, once a company grows in size, geographical expansion, and complexity, increased attention is granted to the practices supporting the communities, which could improve the company performances. Husted [92] proved that, when companies take social-responsibility actions directed at local communities, they benefit of advantages such as image improvement. Unlike this opinion, Berman et al. [93] underlined that the empirical evidence shows a negative relation between CSR practices addressed to the local communities and CFP. Considering these insights, the following hypothesis is elaborated:

Hypothesis 5 (H5). There is a positive relation between CSR practices related to local communities and CFP.

Many companies in Romania perform CSR activities in the field of education and healthcare. This study identified these two activities as separate CSR elements, CSR activities related to education and to healthcare, respectively. The companies develop social practices in activity sectors supporting or/strengthening business strategies in fields such as education and healthcare. Thus, the following hypotheses are developed:

Hypothesis $\mathbf{6}(\mathbf{H 6})$. There is a positive relation between education-related CSR practices and CFP.

Hypothesis 7 (H7). There is a positive relation between healthcare-related CSR practices and CFP.

\section{Research Methods}

\subsection{Multivariate Analysis}

This paper aims at empirically analyzing the relationship between the CSR and the CFP. Moreover, we investigate which of the policies developed by the companies in the form of CSR practices influence the CFP. Therefore, this study investigates the effects of CSR policies from a multidimensional perspective, namely towards the employees, clients, environment, local communities, social activities in relation to education and healthcare, on CFP.

In this sense, a questionnaire was developed as a means to collect the data identifying the policies regarding the social-responsibility practices of the companies listed on the BSE and to understand which amongst the CSR activities influences CFP.

The questionnaire comprises 44 questions and is in accordance with the previous studies carried out by international organizations, namely, the World Bank [94,95], United Nations Development Program [96], and the European Commission recommendations [97] regarding CSR awareness in developing and emerging countries. The questionnaire was sent by email to all the companies listed on the BSE. The data were collected November 2014-July 2015. From 83 companies listed on the BSE in the financial year 2014, only 65 answered our survey. From this sample, we did not consider the answers of three companies, as they were incomplete. Thus, our sample consists of 62 companies, and, respectively, our observations.

The survey was divided into seven sections, respectively on the types of CSR policies. Section 1 examines companies' perspectives related to the CSR concept. This section was composed of 12 questions with YES and NO response variants. Within these 12 questions, 4 had multiple-answer questions in order to capture the companies' vision regarding the CSR concept and their suggestions related to CSR practices. The rest of the sections, namely 6, had response variants with YES and NO only and their focus was on CSR policies adopted by the companies as CSR practices in relation with the 6 types of stakeholders (employees, clients, local communities, environment, education, and health). Thus, Section 2 analyses the CSR policies related to companies' employees and was composed of 7 questions; Section 3 regarded polices related to actual and new employees of the 
company-4 questions; Section 4 referred to polices related to actual company customers- 8 questions; Section 5 underlined polices related to environment protection -5 questions; Section 6 cached polices related to local communities -6 questions; and Section 7 showed polices related to health-2 questions. Answers with Yes were coded with 1 and answers with No with 0 . Consideration of the multiple-answer questions resulted in 78 variables, namely questions.

In line with References [98-106], the questionnaire data were processed using Principal Component Analysis (henceforth "PCA") and a tetrachoric matrix in STATA in order to develop a CSR global index (CSRGI) and specific CSR indices. Poroy Arsoy, Arabaci, and Çiftçioğlu [106] acknowledged the concerns when developing an index, namely: choosing component indicators (since the majority indices employ merely not many variables and it is regularly crucial to utilize further variables), core variables must be transformed to well-suited scales with the purpose of joint, as well as the selection of weights for every of the original variables. Therefore, PCA appears a suitable method given that it allows for a huge number of variables to be engaged and to exploit correlation matrix. Thus, all CSR policies were calculated as CSRGI and every single policy was calculated in the form of specific CSR indices. One CSR policy regards one stakeholder. Thus, there would be six CSR policies as there are six stakeholders.

The multivariate technique of principal component analysis aims to condense the 78 variables, depicting the questions out of the survey to a smaller number of uncorrelated variables, titled principal components (henceforth "PC"), which cover most of the information. The first PC accounts for the maximum variance in the survey dataset, being a linear combination of the original predictor variables, the second PC takes the remaining variance in the survey dataset and is uncorrelated with the first PC, while the algorithm is analogous for the following PC. The initial causal space covers 78 variables ( $q 1$, $q 2, \ldots, q 77, q 78)$, namely, the questions of the questionnaire that are employed towards development of a CSR global index and specific CSR indices. For instance, every company that replied to the survey is featured by 78 variables. Hence, the principal components are described via a vector labelled with $w$, as follows:

$$
w=\left(\begin{array}{c}
w_{1} \\
w_{2} \\
\cdots \\
w_{77} \\
w_{78}
\end{array}\right)
$$

The linear combination corresponding to a principal component can be represented as below $\left(w_{i}\right.$ signifies each vector coordinate, as described previously):

$$
w_{i}=\alpha_{1}^{(i)} \times q_{1}+\alpha_{2}^{(i)} \times q_{2}+\ldots+\alpha_{77}^{(i)} \times q_{77}+\alpha_{78}^{(i)} \times q_{78} \quad i=1,2, \ldots, 77,78
$$

where $i$ represents the number of questions from the survey, coefficients $\alpha_{j}^{(i)}$ are the eigenvectors of the correlation matrix related to the former variables $q 1, q 2, \ldots, q 77, q 78$, whilst the eigenvalues of the correlation matrix are the variances of the principal components.

The coefficients $\left(\alpha_{1}^{(i)}, \alpha_{2}^{(i)}, \ldots, \alpha_{77}^{(i)}, \alpha_{78}^{(i)}\right)$ of the linear combination showed previously are the coordinates of the vector $\alpha^{(i)}$ :

$$
\alpha^{(i)}=\left(\begin{array}{c}
\alpha_{1}^{(i)} \\
\alpha_{2}^{(i)} \\
\ldots \\
\alpha_{77}^{(i)} \\
\alpha_{78}^{(i)}
\end{array}\right) \quad i=1,2,7 \ldots 77,78
$$


The vectors $\alpha^{(i)}$ depict the columns of the matrix $A 78 \times 78$, as follows:

$$
A=\left(\begin{array}{ccccc}
\alpha_{1}^{(1)} & \alpha_{1}^{(2)} & \ldots & \alpha_{1}^{(77)} & \alpha_{1}^{(78)} \\
\alpha_{2}^{(1)} & \alpha_{2}^{(2)} & \ldots & \alpha_{2}^{(77)} & \alpha_{2}^{(78)} \\
\ldots & \ldots & \ldots & \ldots & \ldots \\
\alpha_{77}^{(1)} & \alpha_{77}^{(2)} & \ldots & \alpha_{77}^{(77)} & \alpha_{77}^{(78)} \\
\alpha_{78}^{(1)} & \alpha_{78}^{(2)} & \ldots & \alpha_{78}^{(77)} & \alpha_{78}^{(78)}
\end{array}\right)
$$
system:

Further, the linear combinations of the principal components are presented through the following

$$
\left\{\begin{array}{c}
w_{1}=\alpha_{1}^{(1)} \times q_{1}+\alpha_{2}^{(1)} \times q_{2}+\ldots+\alpha_{77}^{(1)} \times q_{77}+\alpha_{78}^{(1)} \times q_{78} \\
w_{2}=\alpha_{1}^{(2)} \times q_{1}+\alpha_{2}^{(2)} \times q_{2}+\ldots+\alpha_{77}^{(2)} \times q_{77}+\alpha_{78}^{(2)} \times q_{78} \\
\ldots \ldots \ldots \ldots \ldots \ldots \ldots \ldots \ldots \ldots \ldots \ldots \ldots \ldots \ldots \ldots \ldots \ldots \ldots \ldots \\
w_{77}=\alpha_{1}^{(77)} \times q_{1}+\alpha_{2}^{(77)} \times q_{2}+\ldots+\alpha_{77}^{(77)} \times q_{77}+\alpha_{78}^{(77)} \times q_{78} \\
w_{78}=\alpha_{1}^{(78)} \times q_{1}+\alpha_{2}^{(78)} \times q_{2}+\ldots+\alpha_{77}^{(78)} \times q_{77}+\alpha_{78}^{(78)} \times q_{78}
\end{array}\right.
$$

In a reduced form, the PCA is depicted as follows:

$$
\left\{\begin{array}{c}
\max \operatorname{Var}(w) \\
w=A^{t} q
\end{array}\right.
$$

\subsection{Regression Analysis}

After analyzing the questionnaire data using the PCA method, the CSRGI was developed, as well as the CSR specific indices that would be included in the multivariate regression model to examine the CSR-CFP relation. In the literature review, the researchers reported mixed results on the relation between CSR and CFP (positive, negative, or no relation at all). Hillman and Keim [107] state that researchers used in their models accounting measures or market measures for CFP give an explanation in this sense. For this reason, we considered in our regression model both accounting and market profitability indicators for the companies in our sample. These indicators are given in Table 1.

Table 1. Variables considered for corporate financial performance (CFP).

\begin{tabular}{ccc}
\hline Indicators & Subindicators & Symbol \\
\hline \multirow{2}{*}{ Profitability } & Return on assets & ROA \\
& Return on equity & ROE \\
& Return on invested capital & ROIC \\
\hline \multirow{2}{*}{ Company performance based on market indicators } & Earnings per share & EPS \\
& Price to book value & PBV \\
\hline
\end{tabular}

Source: authors' own work.

Table 2 presents variables that would be used in the regression model as well as their symbol and type (dependent or independent). In order to measure the company size, several authors have proposed different proxy variables when analyzing the CSR-CFP relation, such as total assets $[108,109]$ and total number of company employees [110]. Thus, we considered two variables for the company size, namely: total assets (TA) and total number of employees (TNE). According to previous research, company leverage is important as a control variable when analyzing the relation between CSR and CFP [15]. In this respect, the most frequently used variable as a proxy for company leverage is the ratio between long-term debts and shareholders' equity—TLD/SE [53]—or total debts to shareholders equity (TD/SE), as well as total assets to shareholders equity-TA/SE [111]. Consequently, we considered three variables for the company leverage. 
Table 2. Variables description used in the regression models.

\begin{tabular}{ccc}
\hline Variable & Symbol & Type of Variable \\
\hline Return on equity & ROE & Dependent \\
Return on assets & ROA & Dependent \\
Return on invested capital & ROIC & Dependent \\
Earnings per share & EPS & Dependent \\
Price to book value & PBV & Dependent \\
Corporate social responsibility & CSR & Independent \\
Turnover/employee & TO/E & Control \\
Company size-total assets & TA & Control \\
Company size-total number of employees & TNE & Control \\
Years since listing on Bucharest Stock Exchange (BSE) & Tenure & Control \\
Leverage-long-term debt/shareholders' equity & LTD/SE & Control \\
Leverage-total debt/shareholders' equity & TD/SE & Control \\
Leverage-total assets/shareholders' equity & TA/SE & Control \\
\hline
\end{tabular}

Source: authors' own work.

The employees who are fairly treated and respected by the company enhance their performance at their workplace, thus leading to an increase in CFP [43]. For this reason, we considered that a variable such as the ratio of turnover to total number of employees (TO/E) is important when analyzing the CSR-CFP relation. This variable can explain the relation between CSR policies with company employees and the CFP. The number of years since a company is listed (tenure) can explain CSR policies toward all the six stakeholders, as well as the awareness and importance a company gives to CSR practices [112-114]. Therefore, this variable is considered to be a control variable in our regression models.

Dependent and independent variables with more than one measure were considered one by one in all our regression models. In this way, a better understanding and interpretation of the results is given, as well as the comparison in using different measures for one variable (leverage, company size, and $\mathrm{CFP}$ ).

Figure 1 illustrates summaries of the relation between the variables employed in the empirical analyses.

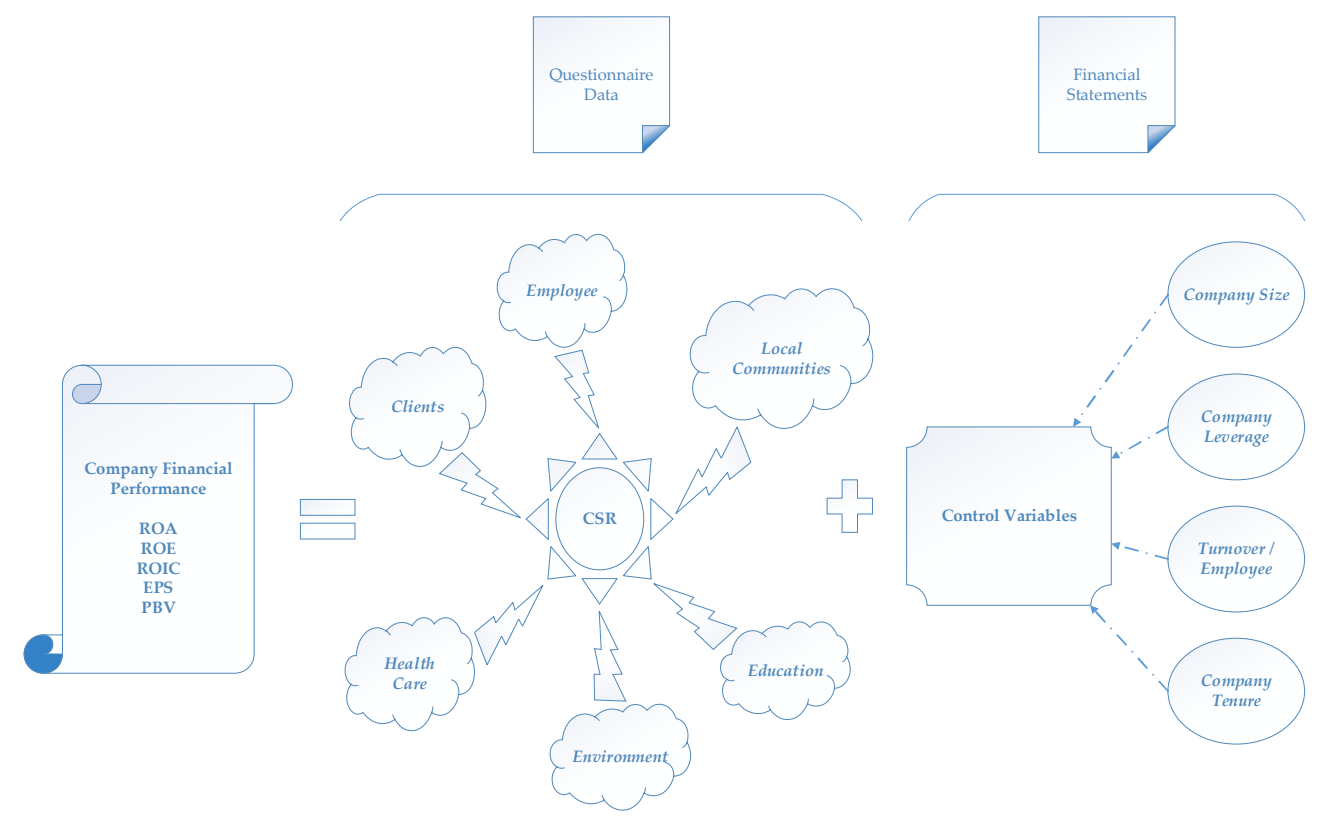

Figure 1. The drivers of company financial performance: CSR and control variables. (Source: authors' own work.). 
The regression method used is OLS for companies listed on the BSE that answered to our questionnaire. The financial data were collected from BSE for the analyzed period, respectively, for the financial year 2014. In order to analyze the CSR-CFP relation, the indices resulted from PCA will be estimated in the cross-sectional regression models by replacing CSR with CSRGI and CSR specific indices:

$$
\text { CFP }_{i}=\alpha+\beta_{1} \text { CSR }_{i}+\beta_{2} \text { TO } / E_{i}+\beta_{3} \text { Tenure }_{i}+\beta_{4} \text { Leverage }_{i}+\beta_{5} \text { Size }_{i}+e_{i}
$$

where $C F P_{i}$ is the company financial performance (return on assets (ROA), return on equity (ROE), return on invested capital (ROIC), earnings per share (EPS), and price to book value (PBV)); $\alpha$ is the intercept term; $\beta_{1}, \beta_{2}, \beta_{3}, \beta_{4}$ are the independent variables coefficients; $\operatorname{CSR}_{i}$ is the variable for CSRGI and its specific indices (as will result from the eigenvalue of the tetrachoric correlation matrix); Tenure $_{i}$; Leverage $_{i}$, and Size $_{i}$ are the controlled variables, and $e_{i}$ is the error term.

Thus, each dependent variable was estimated five times from the consideration of three different measures of company leverage (LTD/SE, TD/SE, TA/SE) and two measures of company size (TA, TNE). Moreover, each of these five models was estimated in separate models by taking, in turn, the five dependents variables for CFP (ROA, ROE, ROIC, EPS, PBV). Beside the different measures of company profitability, leverage, and size, all the models were regressed again by including in the models of the indices that resulted from the PCA.

\section{Empirical Findings}

\subsection{The Outcome of Principal Component Analysis}

This paper analyses the CSR-CFP relation. Our sample consists of 62 companies listed on the BSE and that answered our questionnaire. The period considered in our paper is the financial year 2014. In order to obtain CSRGI- and CSR-specific indices and to integrate them in the multivariate regression model, we used the PCA method.

Table 3 shows the eigenvalue of the tetrachoric correlation matrix of the present paper questionnaire data. We can see from Table 3 that the first principal component explains $26 \%$ from the total variance, the second PC explains $10.48 \%$ of the total variance, the third PC $8.70 \%$, the fourth PC 7.66\%, the fifth PC 6.76\%, the sixth PC 5.56\%, and the seventh PC 5.07\%. According to the Kaiser criterion [115], the PC to retain should be the one with the eigenvalue higher than 1 . Thus, the present paper considered $16 \mathrm{PC}$.

The eigenvalue of the correlation matrix from Figure 2 shows that after the second point, which corresponds to the second PC, the slope reduces [116]. We retained the first seven PC as they cumulated $70.24 \%$ from the total information.

Because of the lack of high correlation between PC and the original variables, we applied Promax oblique rotation. The results showed that the first PC is strongly correlated with the CSR policies regarding companies' employees and environmental protection. Because these policies reflect company concerns regarding social practices toward the environment, we called this CSR specific index IEnvironment. The second PC is correlated with the period (less than one year) since companies start to implement CSR practices such as environmental protection, human rights, health, and local communities. Because these CSR practices reflect more the local communities' needs and requirements implemented by the companies not from a longer period, but a shorter period, we labeled this specific CSR index IComunity1. The third PC is correlated with the CSR practices that regard employees' health and safety at their workplace. We defined this specific CSR index IEmployees. The fourth PC is correlated with CSR policies toward feedback and company dialog with all stakeholders. Because this specific CSR index regards companies' CSR practices toward transparency and business ethics, we entitled it IEthics. The fifth PC is correlated with the company understanding and knowledge of, and information about, CSR, with regard to existing European regulations in promoting the implementation and importance of CSR practices. We identified this specific CSR index as the awareness of the CSR 
concept IAwarenessCSR. The sixth PC is correlated with the future period concerning CSR-practices implementation. Thus, this PC regards CSR practices with environmental protection, health, and local community needs and requirements. We named this specific CSR index IComunity2 because it regards the companies' periods since they started to implement social activity for longer than one year in this case. Thus, IComunity 1 and IComunity 2 are two indices that also relate with the period since companies start to adopt social practices. The last PC, the seventh, is correlated with types of CSR regulations and international standards followed by companies when implementing these practices. We labeled this specific CSR index IStandards.

Table 3. Eigenvalue of the tetrachoric correlation matrix.

\begin{tabular}{|c|c|c|c|c|}
\hline Principal Component & Eigenvalue & Difference & $\%$ Proportion & Cumulative- $\%$ \\
\hline Comp1 & 19.2433 & 11.4879 & 0.26 & 0.26 \\
\hline Comp2 & 7.75538 & 1.31433 & 0.1048 & 0.3648 \\
\hline Comp3 & 6.44105 & 0.772734 & 0.087 & 0.4519 \\
\hline Comp4 & 5.66832 & 0.664356 & 0.0766 & 0.5285 \\
\hline Comp5 & 5.00396 & 0.891264 & 0.0676 & 0.5961 \\
\hline Comp6 & 4.1127 & 0.361086 & 0.0556 & 0.6517 \\
\hline Comp7 & 3.75161 & 0.768874 & 0.0507 & 0.7024 \\
\hline Comp8 & 2.98274 & 0.142611 & 0.0403 & 0.7427 \\
\hline Comp9 & 2.84013 & 0.584543 & 0.0384 & 0.7811 \\
\hline Comp10 & 2.25558 & 0.285681 & 0.0305 & 0.8116 \\
\hline Comp11 & 1.9699 & 0.116186 & 0.0266 & 0.8382 \\
\hline Comp12 & 1.85372 & 0.166824 & 0.0251 & 0.8632 \\
\hline Comp13 & 1.68689 & 0.453365 & 0.0228 & 0.886 \\
\hline Comp14 & 1.23353 & 0.081975 & 0.0167 & 0.9027 \\
\hline Comp15 & 1.15155 & 0.0499443 & 0.0156 & 0.9182 \\
\hline Comp16 & 1.10161 & 0.110489 & 0.0149 & 0.9331 \\
\hline Comp17 & 0.991118 & 0.336109 & 0.0134 & 0.9465 \\
\hline Comp18 & 0.655008 & 0.0548978 & 0.0089 & 0.9554 \\
\hline Comp19 & 0.600111 & 0.0978576 & 0.0081 & 0.9635 \\
\hline Comp20 & 0.502253 & 0.0159207 & 0.0068 & 0.9703 \\
\hline Comp21 & 0.486332 & 0.0544839 & 0.0066 & 0.9768 \\
\hline Comp22 & 0.431848 & 0.0967198 & 0.0058 & 0.9827 \\
\hline Comp23 & 0.335129 & 0.0646087 & 0.0045 & 0.9872 \\
\hline Comp24 & 0.27052 & 0.0665215 & 0.0037 & 0.9909 \\
\hline Comp25 & 0.203999 & 0.0504467 & 0.0028 & 0.9936 \\
\hline Comp26 & 0.153552 & 0.0188292 & 0.0021 & 0.9957 \\
\hline Comp27 & 0.134723 & 0.0598185 & 0.0018 & 0.9975 \\
\hline Comp28 & 0.0749042 & 0.00860623 & 0.001 & 0.9985 \\
\hline Comp29 & 0.0662979 & 0.0266169 & 0.0009 & 0.9994 \\
\hline Comp30 & 0.039681 & 0.037094 & 0.0005 & 1 \\
\hline Comp31 & 0.00258702 & 0.00258702 & 0 & 1 \\
\hline Comp32 & 0 & 0 & 0 & 1 \\
\hline Comp33 & 0 & 0 & 0 & 1 \\
\hline Comp34 & 0 & 0 & 0 & 1 \\
\hline
\end{tabular}

For Comp35-Comp74: Eigenvalue $=0$, Difference $=0$, Proportion $=0$, Cumulative $=1$. (Source: Authors calculations.). 


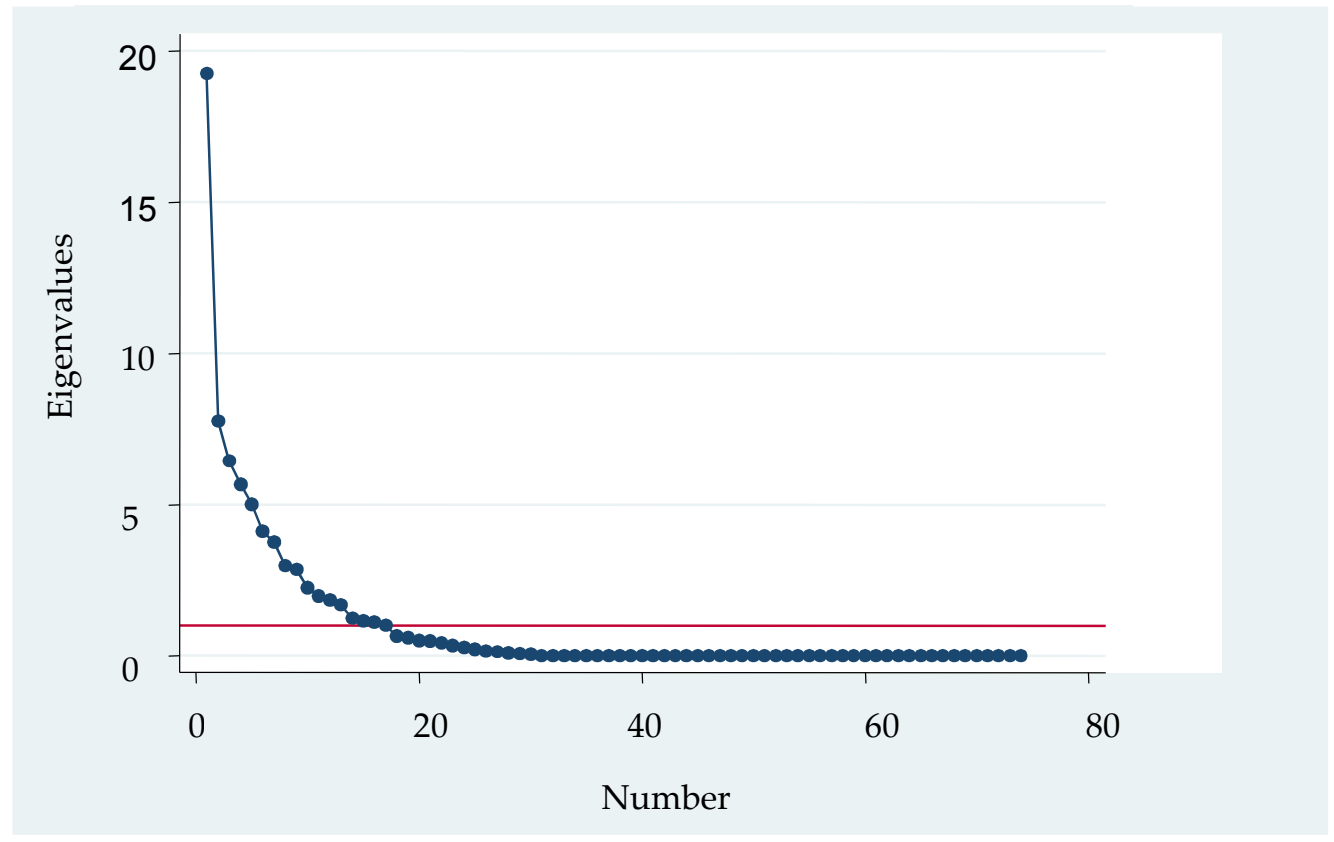

Figure 2. Screen plot of eigenvalues after PCA. (Source: authors' own work.)

After obtaining the PC scores in STATA, their linear combination with its original values have resulted in the seven specific CSR indices detailed above. Given the information content, we calculated the importance coefficients for each of the seven PC, in line with Reference [117]. Thus, the coefficient of importance for the first factor is noted with $C I_{1}$, respectively the variance of the first PC with $\operatorname{var}\left(w_{1}\right), C I_{1}=\operatorname{var}\left(w_{1}\right) / \sum_{j=1}^{7} \operatorname{var}\left(w_{j}\right)$. The following values have resulted for the coefficient of importance: $C I_{1}=0.370159 ; C I_{2}=0.149203 ; C I_{3}=0.123861 ; C I_{4}=0.109055 ; C I_{5}=0.096241$; $C I_{6}=0.079157 ; C I_{7}=0.072181$. The CSRGI for companies that answered our survey and were listed on the BSE for the fiscal year 2014 resulted as follows: CSRGI $=\sum_{j=1}^{7} C_{i}(j) \times w_{j}$.

\subsection{The Output of Cross-Sectional Regression Models}

Table 4 shows the regression result models with ROA as dependent variables having as an independent variable for CSR, the CSRGI, and specific indices. The control variable TNE for the company dimension is statistically significant, whereas TA is not statistically significant in any of the models, even when we took into consideration robust standard errors. Company leverage is the other control variable from the three different measures we used, of which only two are statistically significant, i.e., LTD/SE and TA/SE, in all the models having ROA as the dependent variable. The statistically significant controlled variables remained as such even after we considered for heteroskedasticity as well.

The first model estimations (1) show a positive and statistically significant relation between IEnvironment and ROA. Thus, an increase of $1 \%$ of CSR practices with environment protection would increase CFP by approximately $16.5 \%$. In this model, all independent variables remained statistically significant even after we considered robust standard errors. The coefficient variable of the specific CSR index IComunitty1 is statistically significant but has a negative influence on ROA (the second model-2). Our result reinforces the Berman, Wicks, Kotha, and Jones [93] study. Thus, H5 is not validated when considering ROA as proxy for CFP. This result might be explained by the lack of knowledge or clear norms and regulations on how to successfully implement CSR practices. As underlined by Badulescu et al. [118], CSR practices regarding communities are preferred by the companies from all other social activities. Young companies show interest in implementing CSR activities related to community-programs development, although their involvement in CSR practices is reduced [118]. 
Table 4. The estimations of cross-sectional regression models towards the influence of CSR global index (CSRGI), CSR specific indices, and controls on ROA.

\begin{tabular}{|c|c|c|c|c|c|c|c|c|c|c|c|}
\hline & (1) & (2) & (3) & (4) & (5) & (6) & (7) & (8) & (9) & (10) & (11) \\
\hline IEnvironment & $\begin{array}{l}\mathbf{0 . 0 1 6 5 *} \\
(2.1209)\end{array}$ & & & & & & & & & & \\
\hline TNE & $\begin{array}{c}\mathbf{0 . 0 0 0 0 0 0 2 6 4}{ }^{* *} \\
(3.3799)\end{array}$ & $\begin{array}{c}0.000000105 \\
(0.9706)\end{array}$ & $\begin{array}{c}0.000000216 * \\
(2.2636)\end{array}$ & $\begin{array}{c}0.000000238 * \\
(2.4112)\end{array}$ & & $\begin{array}{c}\mathbf{0 . 0 0 0 0 0 0 1 8 9} \\
(2.0589)\end{array}$ & $\begin{array}{c}0.000000333 \\
(2.6465)\end{array}$ & & $\begin{array}{c}\mathbf{0 . 0 0 0 0 0 0 3 5 3} \text { *** } \\
(3.8386)\end{array}$ & & $\begin{array}{c}\mathbf{0 . 0 0 0 0 0 0 2 7 4} \\
(3.4431)\end{array}$ \\
\hline LTD/SE & $\begin{array}{c}-\mathbf{0 . 0 0 1 7 2} * * * \\
(-5.5425)\end{array}$ & $\begin{array}{c}-\mathbf{0 . 0 0 1 8 9} * * * \\
(-6.1176)\end{array}$ & $\begin{array}{c}-\mathbf{0 . 0 0 1 6 0} 0^{* * *} \\
(-5.3969)\end{array}$ & $\begin{array}{c}-\mathbf{0 . 0 0 1 3 8} 8^{* * *} \\
(-5.8569)\end{array}$ & & $\begin{array}{c}-\mathbf{0 . 0 0 1 7 5} * * * \\
(-5.7358)\end{array}$ & $\begin{array}{c}-\mathbf{0 . 0 0 1 2 2} * * * \\
(-4.7488)\end{array}$ & & $\begin{array}{c}-0.000802^{\dagger} \\
(-1.9579)\end{array}$ & & $\begin{array}{c}-0.00158^{* * *} \\
(-5.9995)\end{array}$ \\
\hline Tenure & $\begin{array}{c}-0.00235^{+} \\
(-1.7608)\end{array}$ & $\begin{array}{l}-0.00197 \\
(-1.5401)\end{array}$ & $\begin{array}{l}-0.00239^{+} \\
(-2.0032)\end{array}$ & $\begin{array}{c}-\mathbf{0 . 0 0 2 2 2}{ }^{+} \\
(-1.7199)\end{array}$ & $\begin{array}{l}-0.00138 \\
(-1.3465)\end{array}$ & $\begin{array}{c}-0.00219^{+} \\
(-1.7687)\end{array}$ & $\begin{array}{c}-0.00255^{+} \\
(-1.9496)\end{array}$ & $\begin{array}{l}-0.00137 \\
(-1.3894)\end{array}$ & $\begin{array}{l}-0.00220 \\
(-1.4820)\end{array}$ & $\begin{array}{l}-0.00122 \\
(-1.1233)\end{array}$ & $\begin{array}{c}-0.00223 \\
(-1.7631)\end{array}$ \\
\hline $\mathrm{TO} / \mathrm{E}$ & $\begin{array}{c}-\mathbf{2 . 3 6 e}-\mathbf{0 8} \mathbf{8}^{* * *} \\
(-3.7283)\end{array}$ & $\begin{array}{c}-3.06 e-08 \text { *** } \\
(-5.7960)\end{array}$ & $\begin{array}{c}-2.77 \mathrm{e}-08^{* * * *} \\
(-4.8508)\end{array}$ & $\begin{array}{c}-2.11 \mathrm{e}-08 \text { ** } \\
(-3.1667)\end{array}$ & $\begin{array}{c}-5.87 \mathrm{e}-09 \\
(-1.1060) \\
\end{array}$ & $\begin{array}{c}-2.46 \mathrm{e}-08^{* * *} \\
(-3.8448)\end{array}$ & $\begin{array}{c}-1.19 \mathrm{e}-08 \\
(-1.2652)\end{array}$ & $\begin{array}{c}2.03 e-09 \\
(0.3726)\end{array}$ & $\begin{array}{c}-9.06 \mathrm{e}-09 \\
(-0.9979)\end{array}$ & $\begin{array}{c}3.06 \mathrm{e}-09 \\
(0.5556)\end{array}$ & $\begin{array}{c}-2.38 \mathrm{e}-08^{* * *} \\
(-4.1215)\end{array}$ \\
\hline TA & & & & & $\begin{array}{c}1.68 \mathrm{e}-10 \\
(0.3945)\end{array}$ & & & $\begin{array}{c}5.53 \mathrm{e}-10 \\
(1.0513)\end{array}$ & & $\begin{array}{c}5.89 \mathrm{e}-10 \\
(1.0778)\end{array}$ & \\
\hline TA/SE & & & & & $\begin{array}{c}-0.0185 \\
* * * \\
(-6.7846)\end{array}$ & & & $\begin{array}{c}-0.0203 \\
* * * \\
(-8.0596)\end{array}$ & & $\begin{array}{c}-\mathbf{0 . 0 1 9 8} \\
* * * \\
(-4.8635)\end{array}$ & \\
\hline IComunitty 1 & & $\begin{array}{l}-0.0234^{* *} \\
(-3.3683)\end{array}$ & & & & & & & & & \\
\hline IEmployees & & & $\begin{array}{c}\mathbf{0 . 0 2 2 8} \text { * }^{* *} \\
(3.0118)\end{array}$ & & & & & & & & \\
\hline IEhtics & & & & $\begin{array}{l}\mathbf{0 . 0 1 6 9 ^ { + }} \\
(2.0213)\end{array}$ & $\begin{array}{l}\mathbf{0 . 0 1 2 8}^{+} \\
(1.8652)\end{array}$ & & & & & & \\
\hline IAwarenessCSR & & & & & & $\begin{array}{l}0.0212 * \\
(2.4265)\end{array}$ & & & & & \\
\hline IComunity2 & & & & & & & $\begin{array}{l}-0.00398 \\
(-0.4353)\end{array}$ & $\begin{array}{l}-0.00278 \\
(-0.3537)\end{array}$ & & & \\
\hline IStandards & & & & & & & & & $\begin{array}{c}0.0193 \\
(1.0062)\end{array}$ & $\begin{array}{l}\mathbf{0 . 0 0 3 6 9} \\
(0.2639)\end{array}$ & \\
\hline CSRGI & & & & & & & & & & & $\begin{array}{l}0.0372 * \\
(2.5035)\end{array}$ \\
\hline _cons & $\begin{array}{c}0.0232 \\
(0.7639)\end{array}$ & $\begin{array}{l}\mathbf{0 . 0 3 8 1}^{+} \\
(1.9276)\end{array}$ & $\begin{array}{l}-0.00463 \\
(-0.1726)\end{array}$ & $\begin{array}{c}0.0277 \\
(1.1170)\end{array}$ & $\begin{array}{c}0.05777^{* *} \\
(2.8046)\end{array}$ & $\begin{array}{l}\mathbf{0 . 0 3 9 0 ^ { + }} \\
(1.8502)\end{array}$ & $\begin{array}{c}0.0659^{* *} \\
(3.3842)\end{array}$ & $\begin{array}{c}\mathbf{0 . 0 8 5 7 * * *} \\
(5.3549)\end{array}$ & $\begin{array}{c}0.0390 \\
(1.0855)\end{array}$ & $\begin{array}{l}0.0789^{*} \\
(2.2605)\end{array}$ & $\begin{array}{l}0.00459 \\
(0.1447)\end{array}$ \\
\hline F stat & $27.68^{* * * *}$ & $31.13^{* * * *}$ & $16.35^{* * * *}$ & $23.05 * * *$ & $18.05^{* * * *}$ & $35.29 * * *$ & $18.76^{* * * *}$ & $17.72 * * *$ & $18.97^{* * * *}$ & $22.52 * * * *$ & $23.44^{* * * *}$ \\
\hline$R^{2}$ & 0.271 & 0.339 & 0.341 & 0.212 & 0.418 & 0.278 & 0.103 & 0.358 & 0.156 & 0.358 & 0.297 \\
\hline Obs & 43 & 43 & 43 & 43 & 42 & 43 & 43 & 42 & 43 & 42 & 43 \\
\hline
\end{tabular}

${ }^{\dagger} p<0.10, * p<0.05, * * p<0.01,{ }^{* * *} p<0.001$. The figures in brackets are robust standard errors. The results in bold with no star or cross above lost their significance after we considered for robust standard error. (Source: Authors calculations.). 
Another interpretation of this result may be relative to the period since the company started to implement these CSR practices. In fact, IComunitty 1 is a specific index regarding CSR practices implemented by the companies for less than one year based on local communities' needs and requirements (environmental protection, human rights, and health).

The specific index IEmployees strengthens the previous research results with regard to companies that respect and treat the employees fair increase their CFP [43]. Thus, there is a positive and statistically significant relation between IEmployees and ROA (model 3). Another specific CSR index is IEthics that regards companies' ethics polices. The model (5) that includes the specific index IEthics is the one that has the highest $R^{2}, 0.418$, from Table 4 . Based on these results, companies implementing CSR policies toward ethics increase their CFP and explain the model analyzing the CSR-CFP relation very well. The second model that explain rather well the CSR-CFP relation, according to $R^{2}(0.358)$, is the one that regards the inclusion of international regulations and standards when implementing CSR practices, i.e., IStandards. This result is in line with Sofian and Dumitru [119], who underline that companies reporting and implementing international standards perform better.

Companies that implement international standards as CSR practices related to products quality, employee safety at their work place, and environmental protection increase their CFP. Thus, companies that understand the importance of CSR practices are aware of their benefits. The model (6) confirms that there is a positive and statistical significance between IAwarenessCSR and CFP. Overall, the CSRGI shows a positive influence on CFP when ROA is considered a dependent variable as proxy for company performance. Thus, the first hypothesis of the study is validated, that is, that CSR positively influence the CFP. Moreover, companies' CSR policies related to employees, environment protection, ethics, and international standards and regulations influence CFP. Thus, the study validates $\mathrm{H} 1, \mathrm{H} 2, \mathrm{H} 3, \mathrm{H} 4$, $\mathrm{H} 6$, and $\mathrm{H7}$ for models having ROA as a dependent variable.

Tables 5 and 6 present the regression results for models having ROE as a dependent variable when considering CSRGI- and CSR-specific indices as explanatory variables. As in the models with ROA as a dependent variable, the control variable TNE for company dimension remains statistically significant, whereas TA continues to be insignificant statistically except for in model (11).

Regarding company leverage, all the measures considered are statistically significant in the models having ROE as a dependent variable. Moreover, the statistical significance and the positive influence of IEnvironment, IEmployees, and CSRGI on CFP are maintained for models with ROE as a dependent variable as well. In addition, model (7) out of Table 6 shows not only a positive CSRGI-CFP relation but also has an $\mathrm{R}^{2}$ of 0.623 , meaning that the independent variables explain approximately $62 \%$ of the dependent variable variance, i.e., ROE. In other words, an increase of $1 \%$ in the CSRGI (which comprises all the specific CSR indices) would increase ROE by approximately $25 \%$. Therefore, models having ROE as a dependent variable validate $\mathrm{H} 1, \mathrm{H} 2, \mathrm{H} 4, \mathrm{H} 6$, and $\mathrm{H} 7$.

The regression models having ROIC as a dependent variable were not statistically significant based on the F (Fisher) test, whereas models with EPS and PBV as dependent variables were statistically significant, but no relation was identified between CSRGI and specific indices and CFP based on the Student's t-test. The present paper presented only the results of the models that were statistically significant regardless of their sign or high/low $\mathrm{R}^{2}$. 
Table 5. The estimations of cross-sectional regression models towards the influence of CSR-specific indices (IEnvironment, IComunitty1, IEmployees, IEthics) on ROE.

\begin{tabular}{|c|c|c|c|c|c|c|c|c|c|c|c|c|}
\hline & (1) & (2) & (3) & (4) & (5) & (6) & (7) & (8) & (9) & (10) & (11) & (12) \\
\hline IEnvironment & $\begin{array}{l}\mathbf{0 . 0 4 8 2}^{+} \\
(1.6985)\end{array}$ & $\begin{array}{c}0.0323 \\
(1.1392)\end{array}$ & $\begin{array}{c}0.0156 \\
(1.4673) \\
\end{array}$ & & & & & & & & & \\
\hline TNE & $\begin{array}{c}\mathbf{0 . 0 0 0 0 0 0 7 5 0} \\
* * \\
(3.0128)\end{array}$ & & & $\begin{array}{c}\mathbf{0 . 0 0 0 0 0 0 3 5 1 ~}^{\dagger} \\
(1.9417)\end{array}$ & & & $\begin{array}{c}\mathbf{0 . 0 0 0 0 0 0 5 9 2} \\
* * \\
(3.4989)\end{array}$ & & & $\begin{array}{c}0.000000803 \\
(2.5973)\end{array}$ & & \\
\hline LTD/SE & $\begin{array}{c}-\mathbf{0 . 0 0 4 5 1} * * * \\
(-3.9978)\end{array}$ & & & $\begin{array}{c}-\mathbf{0 . 0 0 4 8 0} 0^{* * *} \\
(-4.8472)\end{array}$ & & & $\begin{array}{c}-\mathbf{0 . 0 0 4 2 0} * * * \\
(-5.6181)\end{array}$ & & & $\begin{array}{c}-0.00322 \text { ** } \\
(-3.1298)\end{array}$ & & \\
\hline Tenure & $\begin{array}{l}-\mathbf{0 . 0 0 7 4 1} * \\
(-2.0308)\end{array}$ & $\begin{array}{l}-0.00586 \\
(-1.6055)\end{array}$ & $\begin{array}{l}-0.00352 \\
(-1.4807)\end{array}$ & $\begin{array}{l}-0.00641 * \\
(-2.0356)\end{array}$ & $\begin{array}{l}-0.00500 \\
(-1.5731)\end{array}$ & $\begin{array}{l}-0.00311 \\
(-1.3485)\end{array}$ & $\begin{array}{c}-0.00753 \text { * } \\
(-2.0867)\end{array}$ & $\begin{array}{l}-0.00582 \\
(-1.5939)\end{array}$ & $\begin{array}{l}-0.00348 \\
(-1.3865)\end{array}$ & $\begin{array}{c}-\mathbf{0 . 0 0 7 1 9} * \\
(-2.0680)\end{array}$ & $\begin{array}{l}-0.00556 \\
(-1.6152)\end{array}$ & $\begin{array}{l}-0.00316 \\
(-1.3633)\end{array}$ \\
\hline $\mathrm{TO} / \mathrm{E}$ & $\begin{array}{c}-5.61 e-08 * \\
(-2.0762)\end{array}$ & $\begin{array}{c}-5.96 \mathrm{e}-08^{* *} \\
(-3.2802)\end{array}$ & $\begin{array}{c}4.25 \mathrm{e}-08 \\
(1.5894)\end{array}$ & $\begin{array}{c}-7.17 e-08 \\
* * * \\
(-4.3403)\end{array}$ & $\begin{array}{c}-6.74 e-08 \\
* * * \\
(-5.9906)\end{array}$ & $\begin{array}{c}3.24 e-08^{+} \\
(1.7037)\end{array}$ & $\begin{array}{c}-7.04 e-08 \text { ** } \\
(-3.4648)\end{array}$ & $\begin{array}{c}-7.10 e-08 \\
* * * \\
(-4.4390)\end{array}$ & $\begin{array}{c}4.27 \mathrm{e}-08^{\dagger} \\
(1.9957)\end{array}$ & $\begin{array}{c}-3.81 e-08 \\
(-1.1820)\end{array}$ & $\begin{array}{c}-4.43 e-08 \text { * } \\
(-2.2534)\end{array}$ & $\begin{array}{r}5.60 e-08 \\
(2.0714)\end{array}$ \\
\hline TA & & $\begin{array}{c}7.22 \mathrm{e}-09 \\
(1.5406)\end{array}$ & $\begin{array}{c}-1.22 \mathrm{e}-09 \\
(-1.2917)\end{array}$ & & $\begin{array}{c}7.26 \mathrm{e}-09 \\
(1.4842)\end{array}$ & $\begin{array}{c}-1.60 \mathrm{e}-09 \\
(-1.5327)\end{array}$ & & $\begin{array}{c}7.12 \mathrm{e}-09 \\
(1.4627)\end{array}$ & $\begin{array}{c}-1.07 \mathrm{e}-09 \\
(-1.0572)\end{array}$ & & $\begin{array}{c}7.77 \mathrm{e}-09^{\dagger} \\
(1.7826)\end{array}$ & $\begin{array}{c}-6.93 \mathrm{e}-10 \\
(-0.8207)\end{array}$ \\
\hline $\mathrm{TD} / \mathrm{SE}$ & & $\begin{array}{c}-0.004966^{+} \\
(-1.8681)\end{array}$ & & & $\begin{array}{c}-0.00503^{\dagger} \\
(-1.8155)\end{array}$ & & & $\begin{array}{c}-\mathbf{0 . 0 0 4 8 7}^{\dagger} \\
(-1.7532)\end{array}$ & & & $\begin{array}{c}-0.00509 * \\
(-2.0540)\end{array}$ & \\
\hline $\mathrm{TA} / \mathrm{SE}$ & & & $\begin{array}{l}-\mathbf{0 . 1 0 2} * * * \\
(-6.9913)\end{array}$ & & & $\begin{array}{c}-\mathbf{0 . 1 0 0} * * * \\
(-8.1336)\end{array}$ & & & $\begin{array}{c}-0.101^{* * *} \\
(-8.2504)\end{array}$ & & & $\begin{array}{c}-\mathbf{0 . 1 0 6} * * * \\
(-7.4122)\end{array}$ \\
\hline IComunitty1 & & & & $\begin{array}{l}-\mathbf{0 . 0 6 2 4}^{*} \\
(-2.3879)\end{array}$ & $\begin{array}{l}-0.0383 \\
(-1.5265)\end{array}$ & $\begin{array}{l}-0.0255^{\dagger} \\
(-1.9286)\end{array}$ & & & & & & \\
\hline IEmployees & & & & & & & $\begin{array}{l}\mathbf{0 . 0 6 9 6}{ }^{+} \\
(1.9369)\end{array}$ & $\begin{array}{c}0.0480 \\
(1.4039) \\
\end{array}$ & $\begin{array}{c}0.0147 \\
(0.9484) \\
\end{array}$ & & & \\
\hline IEthics & & & & & & & & & & $\begin{array}{c}0.0320 \\
(1.3467)\end{array}$ & $\begin{array}{c}0.0148 \\
(0.6966)\end{array}$ & $\begin{array}{l}0.00159 \\
(0.1174)\end{array}$ \\
\hline _cons & $\begin{array}{l}-0.00937 \\
(-0.1071)\end{array}$ & $\begin{array}{l}-0.00122 \\
(-0.0155)\end{array}$ & $\begin{array}{l}\mathbf{0 . 1 9 7} * * * \\
(4.4432)\end{array}$ & $\begin{array}{c}0.0406 \\
(0.9275)\end{array}$ & $\begin{array}{c}0.0333 \\
(0.7855)\end{array}$ & $\begin{array}{l}\mathbf{0 . 2 0 6} \text { **** } \\
(6.3216)\end{array}$ & $\begin{array}{c}-0.0994 \\
(-0.8568)\end{array}$ & $\begin{array}{l}-0.0659 \\
(-0.6236)\end{array}$ & $\begin{array}{l}\mathbf{0 . 1 8 9} \text { *** } \\
(3.6091)\end{array}$ & $\begin{array}{c}0.0412 \\
(0.6864)\end{array}$ & $\begin{array}{c}0.0449 \\
(0.8570)\end{array}$ & $\begin{array}{c}\mathbf{0 . 2 3 4} * * * \\
(4.9251)\end{array}$ \\
\hline F stat & $7.462 * * *$ & $5.373^{* * *}$ & $39.33^{* * *}$ & $10.52^{* * *}$ & $10.63^{* * *}$ & $54.18^{* * *}$ & $19.47^{* * *}$ & $7.053^{* * * *}$ & $37.31^{* * *}$ & $6.241^{* * *}$ & $5.188^{* * *}$ & $30.55^{* * *}$ \\
\hline $\mathrm{R}^{2}$ & 0.172 & 0.215 & 0.627 & 0.190 & 0.219 & 0.638 & 0.231 & 0.245 & 0.624 & 0.0923 & 0.177 & 0.617 \\
\hline Obs & 43 & 46 & 42 & 43 & 46 & 42 & 43 & 46 & 42 & 43 & 46 & 42 \\
\hline
\end{tabular}

${ }^{\dagger} p<0.10,{ }^{*} p<0.05,{ }^{* *} p<0.01,{ }^{* * *} p<0.001$. The figures in brackets are robust standard errors. The results in bold with no star or cross above lost their significance after we considered for robust standard error. (Source: Authors' calculations.). 
Table 6. The estimations of cross-sectional regression models towards the influence of CSRGI- and CSR-specific indices (IAwarenessCSR, ICommunity2, IStandards) on ROE.

\begin{tabular}{|c|c|c|c|c|c|c|c|c|c|c|}
\hline & (1) & (2) & (3) & (4) & (5) & (6) & (7) & (8) & (9) & (10) \\
\hline IAwarenessCSR & $\begin{array}{c}0.0518 \\
(1.5078)\end{array}$ & $\begin{array}{c}0.0328 \\
(1.0349)\end{array}$ & $\begin{array}{c}0.0115 \\
(0.7746)\end{array}$ & & & & & & & \\
\hline TNE & $\begin{array}{c}\mathbf{0 . 0 0 0 0 0 0 6 1 3} \text { * } \\
(2.3521)\end{array}$ & & & $\begin{array}{c}0.00000101 * \\
(2.4138)\end{array}$ & & $\begin{array}{c}\mathbf{0 . 0 0 0 0 0 0 9 9 5} \\
* * \\
(3.1560)\end{array}$ & & $\begin{array}{c}\mathbf{0 . 0 0 0 0 0 0 7 8 2} \text { ** } \\
(3.0339)\end{array}$ & & \\
\hline LTD/SE & $\begin{array}{c}-0.00428 * * \\
(-3.4042)\end{array}$ & & & $\begin{array}{c}-0.00283 \\
(-1.9014)\end{array}$ & & $\begin{array}{l}-0.00150 \\
(-0.7188)\end{array}$ & & $\begin{array}{c}-0.00408^{* * *} \\
(-4.4296)\end{array}$ & & \\
\hline Tenure & $\begin{array}{c}-0.00704 * \\
(-2.0541)\end{array}$ & $\begin{array}{l}-0.00546 \\
(-1.5943)\end{array}$ & $\begin{array}{l}-0.00326 \\
(-1.4198)\end{array}$ & $\begin{array}{c}-0.00770 * \\
(-2.1595)\end{array}$ & $\begin{array}{l}-0.00277 \\
(-1.1577)\end{array}$ & $\begin{array}{c}-0.00677^{\dagger} \\
(-1.7778)\end{array}$ & $\begin{array}{l}-0.00340 \\
(-1.4474) \\
\end{array}$ & $\begin{array}{c}-0.00708^{+} \\
(-1.9952)\end{array}$ & $\begin{array}{l}-0.00573 \\
(-1.5823) \\
\end{array}$ & $\begin{array}{l}-0.00340 \\
(-1.4474) \\
\end{array}$ \\
\hline $\mathrm{TO} / \mathrm{E}$ & $\begin{array}{c}-5.24 \mathrm{e}-08^{+} \\
(-1.8097)\end{array}$ & $\begin{array}{c}-5.65 e-08 * * \\
(-2.9631)\end{array}$ & $\begin{array}{c}4.80 \mathrm{e}-08 \\
(1.6789)\end{array}$ & $\begin{array}{c}-1.96 \mathrm{e}-08 \\
(-0.4854)\end{array}$ & $\begin{array}{c}\mathbf{6 . 1 0 e}-08^{*} \\
(2.1022)\end{array}$ & $\begin{array}{c}-1.23 \mathrm{e}-08 \\
(-0.3312)\end{array}$ & $\begin{array}{c}4.61 \mathrm{e}-08 \\
(1.6245)\end{array}$ & $\begin{array}{c}-5.62 e-08 * \\
(-2.1307)\end{array}$ & $\begin{array}{c}-\mathbf{6 . 0 7 e - 0 8} \text { ** } \\
(-3.2135)\end{array}$ & $\begin{array}{c}4.61 \mathrm{e}-08 \\
(1.6245)\end{array}$ \\
\hline TA & & $\begin{array}{c}7.59 \mathrm{e}-09 \\
(1.6539)\end{array}$ & $\begin{array}{c}-9.48 \mathrm{e}-10 \\
(-1.0763)\end{array}$ & & $\begin{array}{c}-6.60 \mathrm{e}-10 \\
(-0.7202)\end{array}$ & & $\begin{array}{c}-1.06 \mathrm{e}-09 \\
(-1.1464)\end{array}$ & & $\begin{array}{c}7.13 \mathrm{e}-09 \\
(1.5263)\end{array}$ & $\begin{array}{c}-1.06 \mathrm{e}-09 \\
(-1.1464)\end{array}$ \\
\hline $\mathrm{TD} / \mathrm{SE}$ & & $\begin{array}{c}-0.00515^{+} \\
(-1.9767)\end{array}$ & & & & & & & $\begin{array}{c}-\mathbf{0 . 0 0 4 8 6}{ }^{\dagger} \\
(-1.8259)\end{array}$ & \\
\hline $\mathrm{TA} / \mathrm{SE}$ & & & $\begin{array}{l}-\mathbf{0 . 1 0 3} * * * \\
(-6.9396)\end{array}$ & & $\begin{array}{l}-\mathbf{0 . 1 0 7} * * * \\
(-7.4539)\end{array}$ & & $\begin{array}{l}-\mathbf{0 . 1 0 2} * * * \\
(-6.6356)\end{array}$ & & & $\begin{array}{l}-\mathbf{0 . 1 0 2} * * * \\
(-6.6356)\end{array}$ \\
\hline IComunity2 & & & & $\begin{array}{l}-0.00473 \\
(-0.1720)\end{array}$ & $\begin{array}{l}0.00964 \\
(0.4444) \\
\end{array}$ & & & & & \\
\hline IStandards & & & & & & $\begin{array}{c}0.0768 \\
(0.7700)\end{array}$ & & & & \\
\hline CSRGI & & & & & & & $\begin{array}{c}\mathbf{0 . 0 2 4 7} \text { ** } \\
(1.0173)\end{array}$ & $\begin{array}{c}0.107^{\dagger} \\
(1.6903)\end{array}$ & $\begin{array}{c}0.0751 \\
(1.1623)\end{array}$ & $\begin{array}{c}0.0247 \\
(1.0173)\end{array}$ \\
\hline _cons & $\begin{array}{c}0.0486 \\
(0.8565)\end{array}$ & $\begin{array}{c}0.0375 \\
(0.7274)\end{array}$ & $\begin{array}{l}\mathbf{0 . 2 2 2} * * * \\
(5.3463)\end{array}$ & $\begin{array}{l}\mathbf{0 . 1 1 3} * * \\
(3.1592)\end{array}$ & $\begin{array}{l}\mathbf{0 . 2 3 5} * * * \\
(6.6264)\end{array}$ & $\begin{array}{l}0.00960 \\
(0.0679)\end{array}$ & $\begin{array}{l}\mathbf{0 . 1 9 6} 6^{* *} \\
(3.4656)\end{array}$ & $\begin{array}{c}-0.0614 \\
(-0.5416)\end{array}$ & $\begin{array}{c}-0.0400 \\
(-0.3735)\end{array}$ & $\begin{array}{l}0.196^{* *} \\
(3.4656)\end{array}$ \\
\hline F stat & $6.624^{* * *}$ & $5.014^{* *}$ & $36.36^{* * *}$ & $4.290^{* *}$ & $34.11^{* * *}$ & 4.842 ** & $37.90^{* * *}$ & $8.862 * * *$ & $5.053^{* *}$ & $37.90^{* * *}$ \\
\hline $\begin{array}{l}\mathrm{R}^{2} \\
\mathrm{Obs}\end{array}$ & $\begin{array}{c}0.142 \\
43\end{array}$ & $\begin{array}{c}0.201 \\
46\end{array}$ & $\begin{array}{c}0.621 \\
42\end{array}$ & $\begin{array}{c}0.0619 \\
43\end{array}$ & $\begin{array}{c}0.619 \\
42\end{array}$ & $\begin{array}{c}0.130 \\
43\end{array}$ & $\begin{array}{c}0.623 \\
42\end{array}$ & $\begin{array}{c}0.185 \\
43\end{array}$ & $\begin{array}{c}0.224 \\
46\end{array}$ & $\begin{array}{c}0.623 \\
42\end{array}$ \\
\hline
\end{tabular}

$+p<0.10,{ }^{*} p<0.05,{ }^{* *} p<0.01,{ }^{* * *} p<0.001$. The figures in brackets are robust standard errors. The results in bold with no star or cross above lost their significance after we considered for robust standard error. (Source: Authors calculations.). 


\section{Conclusions}

The present paper studied the relation between CSR and CFP for companies listed on BSE over the financial year of 2014. In order to examine in detail this relation, we investigate CSR policies adopted by the companies as CSR practices on CFP. In this sense, we developed seven hypotheses in order to analyze CSR-CFP (first hypothesis) and CSR practices-CFP (six hypotheses). The policies were focused on six types of stakeholders (from where the hypotheses were developed) considered to have influence through CSR practices on CFP. In order to validate our hypotheses, a questionnaire was developed and implemented. The sample consists of 62 companies listed on BSE, respectively those that answered to our questionnaire. The questionnaire data were processed by using PCA, the tetrachoric correlation matrix from which seven PC, seven specific CSR indices, respectively, and a CSRGI, resulted. The novelty of this paper resides in the use of incorporating qualitative with quantitative methods in analyzing the relation between CSR and CFP, as well as CSR practices that influence CFP.

We validated our hypothesis using OLS regression models where integrated CSRGI and CSR specific indices were integrated. In order to detect if there were specification errors, we used in all the models a robust standard error to control for heteroskedasticity. Thus, our results were robust.

The empirical evidence shows the existence of a positive and statistically significant relationship between CSR practices and CFP. The companies listed on the Bucharest Stock Exchange should develop or continue developing their understanding of and capacity to integrate CSR practices in their business strategies, since these activities can increase performance, competitive advantage, strengthening the company position on the addressed product and/or service market. The CSR policies implemented as CSR practices regarding the employees and environment protection are the most important activities adopted by the companies. These practices positively influence CFP. Moreover, CSR practices toward employees' healthcare, security, and safety at their workplace, as well as personal development and social inclusion, led to added development in terms of CSR practices. The specific indices IEmployees and IEnvironment showed a positive influence on CFP, i.e., ROA and ROE.

Companies that consider implementing quality of various products and services based on international standards and regulations (IStandards), as well as taking into consideration the environment in their business strategy, improve their CFP. By developing a CSRGI and specific indicators regarding CSR practices, the benefits of implementing CSR in the company business strategy were validated using empirical methods. According to the specialized literature, business decisions should be governed by or should include moral principles and codes of conduct, namely, company ethics policies (IEthics). In this sense, the specific index from our study regarding the companies' policies ethics proved to have a significant positive influence on CFP. The way the company is perceived by the stakeholders is very important. The companies that became aware of CSR benefits and understood the CSR concept created a socially responsible business model. Such companies communicate with the stakeholders, thus consolidating the company image, competitive advantage and, implicitly, CFP [120]. Thus, the specific index IAwarenessCSR positively influences CFP.

The field of CSR is still unchartered territory, open to exploration, at an early stage of development in Romania; consequently, the study results bring a significant contribution to the specialized literature as regards to this topic in the context of the companies listed on the Bucharest Stock Exchange. Thus, this paper proposed a CSR definition for emerging and developing countries, identified six stakeholders able to influence company performance (company employees, clients, environment, local communities, education, and healthcare), and designed a CSR index validated through empirical methods. Moreover, our study shows the importance of the CSR practice on the company performance, and the role the stakeholders can play in the sustainable development of a company.

According to Directive 95/2014 of the European Union [121], companies need to report their CSR practices as well as their strategies regarding these social actives since 2017 or during 2017. Thus, in 2018 the number of companies that report CSR activities should increase or have their social responsible practices enhanced. The current study is limited to a single year of analysis, i.e., 2014. Therefore, as a 
future research direction, this approach may be extended with a longer period of investigation given the European Union Directive [121]. In this manner, the results can be compared, whether or not the results hold in time. Another important comparison in future direction of research might regard the sustainability of CSR policies, particularly the social activities adopted by the companies.

Author Contributions: These authors contributed equally to this work. All authors read and approved the final manuscript.

Funding: This research received no external funding.

Conflicts of Interest: The authors declare no conflict of interest.

\section{References}

1. Saxton, G.D.; Waters, R.D. What do stakeholders like on Facebook? Examining public reactions to nonprofit organizations' informational, promotional, and community-building messages. J. Public Relat. Res. 2014, 26, 280-299. [CrossRef]

2. Jones, D.A. Does serving the community also serve the company? Using organizational identification and social exchange theories to understand employee responses to a volunteerism programme. J. Occup. Organ. Psychol. 2010, 83, 857-878. [CrossRef]

3. McWilliams, A.; Siegel, D. Corporate social responsibility: A theory of the firm perspective. Acad. Manag. Rev. 2001, 26, 117-127. [CrossRef]

4. Friedman, M. The social responsibility of business is to increase its profits. N. Y. Times Mag. 1970, 9, 32-33.

5. Edenkamp, P. Insights into how consumers are thinking, how they are acting and why? Brandweek 2002, 43, $16-20$.

6. Garriga, E.; Mele, D.N. Corporate social responsibility theories: Mapping the territory. J. Bus. Ethics 2004, 53, 51-71. [CrossRef]

7. Fiori, G.; di Donato, F.; Federica Izzo, M.F. Corporate social responsibility and firms performance-An analysis on italian listed companies. SSRN Electron. J. 2007, 9, 1-14. [CrossRef]

8. Lai, C.S.; Chiu, C.J.; Yang, C.F.; Pai, D.C. The effects of corporate social responsibility on brand performance: The mediating effect of industrial brand equity and corporate reputation. J. Bus. Ethics 2010, 95, 457-469. [CrossRef]

9. Verčič, A.T.; Ćorić, D.S. The relationship between reputation, employer branding and corporate social responsibility. Public Relat. Rev. 2018, in press.

10. Porter, M.E.; Kramer, M.R. The competitive advantage of corporate philanthropy. Harv. Bus. Rev. 2002, 80, 56-68. [PubMed]

11. Turban, D.B.; Greening, D.W. Corporate social performance and organizational attractiveness to prospective employees. Acad. Manag. J. 1997, 40, 658-672.

12. Hemingway, C.A.; Maclagan, P.W. Managers' personal values as drivers of corporate social responsibility. J. Bus. Ethics 2004, 50, 33-44. [CrossRef]

13. Porter, M.E.; Kramer, M.R. Strategy and society: The link between competitive advantage and corporate social responsibility. Harv. Bus. Rev. 2006, 84, 78-92. [PubMed]

14. Welford, R.; Frost, S. Corporate social responsibility in asian supply chains. Corp. Soc. Responsib. Environ. Manag. 2006, 13, 166-176. [CrossRef]

15. McWilliams, A.; Siegel, D. Corporate social responsibility and financial performance: Correlation or misspecification? Strateg. Manag. J. 2000, 21, 603-609. [CrossRef]

16. Weiss, J.W. Business Ethics: A Stakeholder and Issues Management Approach with Cases; South-Western Cengage Learning: Mason, OH, USA, 2009.

17. Agarwal, S.K. Corporate Social Responsibility in India; SAGE Publications India Pvt Ltd.: New Delhi, India, 2008.

18. Reich, R.B. The Case Against Corporate Social Responsibility. Available online: http://dx.doi.org/10.2139/ ssrn.1213129 (accessed on 13 August 2018).

19. Winchester, M.; Romaniuk, J.; Bogomolova, S. Positive and negative brand beliefs and brand defection/uptake. Eur. J. Mark. 2008, 42, 553-570. [CrossRef]

20. Bird, R.; Hall, A.D.; Momente, F.; Reggiani, F. What corporate social responsibility activities are valued by the market? J. Bus. Ethics 2007, 76, 189-206. [CrossRef] 
21. van Beurden, P.; Gossling, T. The worth of values-A literature review on the relation between corporate social and financial performance. J. Bus. Ethics 2008, 82, 407-424. [CrossRef]

22. Sanclemente-Téllez, J.C. Marketing and corporate social responsibility (CSR). Moving between broadening the concept of marketing and social factors as a marketing strategy. Span. J. Mark. ESIC 2017, 21, 4-25. [CrossRef]

23. Freeman, R.E.; Wicks, A.C.; Parmar, B. Stakeholder theory and "the corporate objective revisited". Organ. Sci. 2004, 15, 364-369. [CrossRef]

24. Elms, H. Corporate (and stakeholder) responsibility in central and Eastern Europe. Int. J. Emerg. Mark. 2006, 1, 203-211. [CrossRef]

25. Pan, X.P.; Sha, J.H.; Zhang, H.L.; Ke, W.L. Relationship between corporate social responsibility and financial performance in the mineral industry: Evidence from Chinese mineral firms. Sustainability 2014, 6, 4077-4101. [CrossRef]

26. Chou, L.-C.; Chang, T.-C.; Darcy, J.; Yan, Y.-C. The impact of social responsibility on corporate performance: Evidence from Taiwan. Account. Financ. Res. 2017, 6, 181-189.

27. Senyigit, Y.B.; Shuaibu, M.A. The effect of corporate social responsibility on financial performance: Evidence from the banking industry in emerging economies. J. Bus. Stud. Q. 2017, 9, 22-31.

28. World Bank Group. Global Economic Prospects: The Turning of the Tide? Technical Report for World Bank; World Bank: Washington, DC, USA, 2018.

29. FTSE Russell. Ftse Country Classification-March 2018 Interim Update. Available online: https:/ /www.ftse. com/.../FTSE-Country-Classification-Update_latest.pdf (accessed on 29 August 2018).

30. Lu, W.S.; Chau, K.W.; Wang, H.D.; Pan, W. A decade's debate on the nexus between corporate social and corporate financial performance: A critical review of empirical studies 2002-2011. J. Clean. Prod. 2014, 79, 195-206. [CrossRef]

31. Muruganantham, G. Case study on corporate social responsibility of mnc's in India. In Proceedings of the International Trade and Academic Research Conference, London, UK, 8-10 November 2010.

32. Ariyabandu, M.M.; Hulangamuwa, P. Corporate Social Responsibility and Natural Disaster Reduction in Sri Lanka. Available online: https:/ / assets.publishing.service.gov.uk/media/57a08d32e5274a31e00016de/ R7893Privatesectorstudy.pdf (accessed on 29 August 2018).

33. Hopkins, M. Corporate Social Responsibility and International Development: Is Business the Solution? Earthscan: Sterling, VA, USA, 2012.

34. Justice, D.W. Corporate Social Responsibility: Challenges and Opportunities for Trade Unionists; Cornell University ILR School: Itahca, NY, USA, 2002.

35. Kent, M.L.; Taylor, M. From homo economicus to homo dialogicus: Rethinking social media use in CSR communication. Public Relat. Rev. 2016, 42, 60-67. [CrossRef]

36. Hategan, C.D.; Sirghi, N.; Curea-Pitorac, R.I.; Hategan, V.P. Doing well or doing good: The relationship between corporate social responsibility and profit in Romanian Companies. Sustainability 2018, 10, 1041. [CrossRef]

37. Ionascu, M.; Ionascu, I.; Sacarin, M.; Minu, M. Women on boards and financial performance: Evidence from a European emerging market. Sustainability 2018, 10, 1644. [CrossRef]

38. Manderson, A.K. A systems based framework to examine the multi-contextural application of the sustainability concept. Environ. Dev. Sustain. 2006, 8, 85-97. [CrossRef]

39. Cramer, J.; Jonker, J.; van der Heijden, A. Making sense of corporate social responsibility. J. Bus. Ethics 2004, 55, 215-222. [CrossRef]

40. Lantos, G.P. The boundaries of strategic corporate social responsibility. J. Consum. Mark. 2001, 18, 595-632. [CrossRef]

41. Margolis, J.D.; Walsh, J.P. Misery loves companies: Rethinking social initiatives by business. Admin. Sci. Q. 2003, 48, 268-305. [CrossRef]

42. Fisman, R.; Heal, G.; Nair, V.B. Corporate social responsibility: Doing well by doing good? Bus. Horiz. 2011, 50, 247-254.

43. Dumitrescu, D.; Simionescu, L.N. Empirical research regarding the influence of corporate social responsibility (CSR) activities on companies' employees and financial performance. Econ. Comput. Econ. Cybern. 2015, 49, $57-71$. 
44. Bosch-Badia, M.T.; Montllor-Serrats, J.; Tarrazon, M.A. Corporate social responsibility from friedman to porter and kramer. Theor. Econ. Lett. 2013, 3, 11-15. [CrossRef]

45. Visser, W. Corporate Social Responsibility in Developing Countries; Oxford University Press: New York, NY, USA, 2008.

46. Jackson, G.; Apostolakou, A. Corporate social responsibility in Western Europe: An institutional mirror or substitute? J. Bus. Ethics 2010, 94, 371-394. [CrossRef]

47. Becchetti, L.; Di Giacomo, S.; Pinnacchio, D. Corporate social responsibility and corporate performance: Evidence from a panel of us listed companies. Appl. Econ. 2008, 40, 541-567. [CrossRef]

48. Paul, C.J.M.; Siegel, D.S. Corporate social responsibility and economic performance. J. Prod. Anal. 2006, 26, 207-211. [CrossRef]

49. Mahoney, L.; Roberts, R.W. Corporate social performance, financial performance and institutional ownership in Canadian firms. Account. Forum 2007, 31, 233-253. [CrossRef]

50. Smith, K.T.; Smith, M.; Wang, K. Does brand management of corporate reputation translate into higher market value? J. Strateg. Mark. 2010, 18, 201-221. [CrossRef]

51. Bhattacharyya, S.S. Development of a CSR-strategy-framework. Ph.D. Thesis, Management Development Institute, Gurgaon, India, 7-9 September 2008.

52. Brammer, S.; Millington, A. Does it pay to be different? An analysis of the relationship between corporate social and financial performance. Strateg. Manag. J. 2008, 29, 1325-1343. [CrossRef]

53. Waddock, S.A.; Graves, S.B. The corporate social performance-Financial performance link. Strateg. Manag. J. 1997, 18, 303-319. [CrossRef]

54. Preston, L.E.; O’Bannon, D.P. The corporate social-financial performance relationship. Bus. Soc. 1997, 36, 419-429. [CrossRef]

55. Ali, I.; Rehman, K.U.; Ali, S.I.; Yousaf, J.; Zia, M. Corporate social responsibility influences, employee commitment and organizational performance. Afr. J. Bus. Manag. 2010, 4, 2796-2801.

56. Chen, J.C.; Patten, D.M.; Roberts, R.W. Corporate charitable contributions: A corporate social performance or legitimacy strategy? J. Bus. Ethics 2008, 82, 131-144. [CrossRef]

57. Dhaliwal, D.S.; Li, O.Z.; Tsang, A.; Yang, Y.G. Voluntary nonfinancial disclosure and the cost of equity capital: The initiation of corporate social responsibility reporting. Account. Rev. 2011, 86, 59-100. [CrossRef]

58. Giannarakis, G.; Theotokas, I. The effect of financial crisis in corporate social responsibility performance. Int. J. Mark. Stud. 2011, 3, 2-10. [CrossRef]

59. Dibella, M.; Woodilla, J. Corporate social responsibility and financial performance. Econ. Res. 2006, 30, 676-693.

60. Goss, A.; Roberts, G.S. Corporate social responsibility and the cost of debt financing. In Proceedings of the European Financial Management Association 2009 Annual Meetings, Milan, Italy, 24-27 June 2009.

61. Gupta, D.K.; Saxena, K. Corporate social responsibility in indian service organisations: An empirical study. In Proceedings of the Conference on 'CSRAgendas for Asia', Kuala Lumpur, Malaysia, 13-14 April 2006.

62. Williams, S.M.; Pei, C.-A.H.W. Corporate social disclosures by listed companies on their web sites: An international comparison. Int. J. Account. 1999, 34, 389-419. [CrossRef]

63. Suliman, A.; Al-Khatib, H. Corporate social responsibility and employer branding: A study in the public sector. In Proceedings of the 27th International Business Research Conference, Ryerson University, Toronto, ON, Canada, 12-13 June 2014.

64. Lee, J.; Miller, D. People matter: Commitment to employees, strategy and performance in Korean firms. Strateg. Manag. J. 1999, 20, 579-593. [CrossRef]

65. Volunteering Australia. Employee Volunteering and CSR: Job Seeker Perspectives; Volunteering Australia Inc.: Melbourne, Australia, 2007.

66. Shin, I.; Hur, W.M.; Kang, S. Employees' perceptions of corporate social responsibility and job performance: A sequential mediation model. Sustainability 2016, 8, 493. [CrossRef]

67. Davenport, K. Corporate citizenship: A stakeholder approach for defining corporate social performance and identifying measures for assessing it. Bus. Soc. 2000, 39, 210-219. [CrossRef]

68. Graves, S.B.; Waddock, S.A. Institutional owners and corporate social performance. Acad. Manag. J. 1994, 37, 1034-1046.

69. Wood, D.J. Corporate social performance revisited. Acad. Manag. Rev. 1991, 16, 691-718. [CrossRef] 
70. Glavas, A.; Kelley, K. The effects of perceived corporate social responsibility on employee attitudes. Bus. Ethics Q. 2014, 24, 165-202. [CrossRef]

71. Solomon, R.C.; Hanson, K.R. It's Good Business; Atheneum: New York, NY, USA, 1985.

72. Gond, J.-P.; El Akremi, A.; Jacques Igalens, J.; Swaen, V. A Corporate Social Responsibility—Corporate Financial Performance Behavioural Model for Employees; Cambridge University Press: Cambridge, UK, 2010.

73. Post, J.E.; Preston, L.E.; Sachs, S. Managing the extended enterprise: The new stakeholder view. Calif. Manag. Rev. 2002, 45, 6-28. [CrossRef]

74. Cohen, D.; Prusak, L. In Good Company: How Social Capital Makes Organizations Work; Harvard Business School Press: Cambridge, MA, USA, 2001.

75. Anderson, J.C.; Gerbing, D.W. Structural equation modeling in practice: A review and recommended two-step approach. Psychol. Bull. 1988, 103, 411-423. [CrossRef]

76. Fornell, C.; Mithas, S.; Morgeson, F.V.; Krishnan, M.S. Customer satisfaction and stock prices: High returns, low risk. J. Mark. 2006, 70, 3-14. [CrossRef]

77. Gruca, T.S.; Rego, L.L. Customer satisfaction, cash flow, and shareholder value. J. Mark. 2005, 69, $115-130$. [CrossRef]

78. Walsh, G.; Beatty, S.E. Customer-based corporate reputation of a service firm: Scale development and validation. J. Acad. Mark. Sci. 2007, 35, 127-143. [CrossRef]

79. Anderson, E.W.; Fornell, C.; Mazvancheryl, S.K. Customer satisfaction and shareholder value. J. Mark. 2004, 68, 172-185. [CrossRef]

80. Mosley, R.W. Customer experience, organisational culture and the employer brand. J. Brand Manag. 2007, 15, 123-134. [CrossRef]

81. Lee, S.; Heo, C.Y. Corporate social responsibility and customer satisfaction among us publicly traded hotels and restaurants. Int. J. Hosp. Manag. 2009, 28, 635-637. [CrossRef]

82. Mazurkiewicz, P. Corporate Environmental Responsibility: Is a Common CSR Framework Possible? Technical Report for World Bank; World Bank: Washington, DC, USA, 2004.

83. Mishra, S.; Suar, D. Does corporate social responsibility influence firm performance of Indian companies? J. Bus. Ethics 2010, 95, 571-601. [CrossRef]

84. Klassen, R.D.; McLaughlin, C.P. The impact of environmental management on firm performance. Manag. Sci. 1996, 42, 1199-1214. [CrossRef]

85. Dumitrescu, D.; Simionescu, L.N.; Roman, A. Environmental responsibility and company financial performance: The case of romanian manufacturing industry. Environ. Eng. Manag. J. 2015, 14, 2947-2957. [CrossRef]

86. Elsayed, K.; Paton, D. The impact of environmental performance on firm performance: Static and dynamic panel data evidence. Struct. Chang. Econ. Dyn. 2005, 16, 395-412. [CrossRef]

87. Porter, M.E. Towards a dynamic theory of strategy. Strateg. Manag. J. 1991, 12, 95-117. [CrossRef]

88. Porter, M.E.; Vanderlinde, C. Toward a new conception of the environment-competitiveness relationship. J. Econ. Perspect. 1995, 9, 97-118. [CrossRef]

89. Palmer, K.; Oates, W.E.; Portney, P.R. Tightening environmental standards-The benefit-cost or the no-cost paradigm. J. Econ. Perspect. 1995, 9, 119-132. [CrossRef]

90. Walley, N.; Whitehead, B. It's not easy being green. Harv. Bus. Rev. 1994, 72, 46-52.

91. Lesser, L. Representations of Reversal: Exploring Simpson's Paradox; National Council of Teachers of Mathematics: Reston, VA, USA, 2001.

92. Husted, B.W. Governance choices for corporate social responsibility: To contribute, collaborate or internalize? Long Range Plann. 2003, 36, 481-498. [CrossRef]

93. Berman, S.L.; Wicks, A.C.; Kotha, S.; Jones, T.M. Does stakeholder orientation matter? The relationship between stakeholder management models and firm financial performance. Acad. Manag. J. 1999, 42, 488-506.

94. World Bank. A Better Investment Climate for Everyone; Technical report for World Bank; World Bank: Washington, DC, USA, 2005.

95. World Bank. Opportunities and Options for Governments to Promote Corporate Social Responsibility in Europe and Central Asia. Evidence from Bulgaria, Croatia, and Romania; Technical Report for World Bank; World Bank: Washington, DC, USA, 2005.

96. United Nations Development Program. Beyond Scarcity: Power, Poverty and the Global Water Crisis; Technical Report for UN; UN: New York, NY, USA, 2006. 
97. European Commission. A Global Partnership for Poverty Eradication and Sustainable Development after 2015; European Commission: Brussels, Belgium, 2015.

98. Tu, J.C.; Chiu, P.L.; Huang, Y.C.; Hsu, C.Y. Influential factors and strategy of sustainable product development under corporate social responsibility in Taiwan. Math. Probl. Eng. 2013, 10, 1155. [CrossRef]

99. Delmas, M.A.; Etzion, D.; Nairn-Birch, N. Triangulating environmental performance: What do corporate social responsibility ratings really capture? Acad. Manag. Perspect. 2013, 27, 255-267. [CrossRef]

100. Ferrero-Ferrero, I.; Fernandez-Izquierdo, M.A.; Munoz-Torres, M.J. Integrating sustainability into corporate governance: An empirical study on board diversity. Corp. Soc. Responsib. Environ. Manag. 2015, 22, $193-207$. [CrossRef]

101. Sanchez-Hernandez, M.I.; Gallardo-Vazquez, D.; Barcik, A.; Dziwinski, P. The effect of the internal side of social responsibility on firm competitive success in the business services industry. Sustainability 2016, 8, 179. [CrossRef]

102. Mensah, H.K.; Agyapong, A.; Nuertey, D. The effect of corporate social responsibility on organizational commitment of employees of rural and community banks in Ghana. Cogent. Bus. Manag. 2017, 4, 1-19. [CrossRef]

103. López-Fernández, A.M.; Mansilla, R. Communicating on corporate social responsibility: A method to differentiate among socially responsible firms. Int. J. Sustain. Soc. 2015, 7, 392-404. [CrossRef]

104. Čančer, V.; Žižek, S.Š. The multiple criteria assessment of social responsibility in organizations. Croat. Oper. Res. Rev. 2013, 4, 200-210.

105. Dincer, B. Do the shareholders really care about corporate social responsibility? Int. J. Bus. Soc. Sci. 2011, 2, 71-76.

106. Poroy Arsoy, A.; Arabaci, Ö.; Çiftçioğlu, A. Corporate social responsibility and financial performance relationship: The case of turkey. J. Account. Financ. 2012, 53, 159-176.

107. Hillman, A.J.; Keim, G.D. Shareholder value, stakeholder management, and social issues: What's the bottom line? Strateg. Manag. J. 2001, 22, 125-139. [CrossRef]

108. Hamid, K.; Akash, R.S.I.; Asghar, M.; Ahmad, S. Corporate social performance, financial performance and market value behavior: An information asymmetry perspective. Afr. J. Bus. Manag. 2011, 5, 6342-6349.

109. Choi, J.S.; Kwak, Y.M.; Choe, C. Corporate social responsibility and corporate financial performance: Evidence from Korea. Aust. J. Manag. 2010, 35, 291-311. [CrossRef]

110. Kim, H.R.; Lee, M.; Lee, H.T.; Kim, N.M. Corporate social responsibility and employee-company identification. J. Bus. Ethics 2010, 95, 557-569. [CrossRef]

111. Trebucq, S.; D'Arcimoles, C.-H. The corporate social performance-financial performance link: Evidence from France. SSRN Electron. J. 2002, 5, 1-20. [CrossRef]

112. Gherghina, S.C.; Simionescu, L.N. Does entrepreneurship and corporate social responsibility act as catalyst towards firm performance and brand value? Int. J. Econ. Financ. 2015, 7, 23-34. [CrossRef]

113. Simionescu, L.N.; Gherghina, S.C. Corporate social responsibility and corporate performance: Empirical evidence from a panel of the Bucharest stock exchange listed companies. Manag. Mark. Chall. Knowl. Soc. 2014, 9, 439-458.

114. Huang, S. Board tenure and firm performance. J. Account. Res. 2018, in press. [CrossRef]

115. Kaiser, H.F. The varimax criterion for analytic rotation in factor analysis. Psychometrika 1958, 23, 187-200. [CrossRef]

116. Cattell, R.B. The Data Box: Its Ordering of Total Resources in Terms of Possible Relational Systems; Plenum Press: New York, NY, USA, 1988.

117. Fucec, A.A. New indicators for knowledge organizations. J. Organ. Knowl. Manag. 2012, 7, 1-8.

118. Badulescu, A.; Badulescu, D.; Saveanu, T.; Hatos, R. The relationship between firm size and age, and its social responsibility actions-focus on a developing country (Romania). Sustainability 2018, 10, 805. [CrossRef]

119. Sofian, I.; Dumitru, M. The compliance of the integrated reports issued by European financial companies with the international integrated reporting framework. Sustainability 2017, 9, 1319. [CrossRef] 
120. Simionescu, L.N.; Dumitrescu, D. Corporate social responsibility and financial crisis. In Proceedings of the Monetary, Banking and Financial Issues in Central and Eastern Eu Member Countries: How Can Central and Eastern Eu Members Overcome the Current Economic Crisis? Iași, Romania, 10-12 April 2014; pp. 273-280.

121. The European Parliament and the Council. As Regards Disclosure of Non-Financial and Diversity Information by Certain Large Undertakings and Groups. Available online: https://eur-lex.europa.eu/ legal-content/EN/TXT/PDF/?uri=CELEX:32014L0095\&from=EN (accessed on 13 August 2018).

(c)

(C) 2018 by the authors. Licensee MDPI, Basel, Switzerland. This article is an open access article distributed under the terms and conditions of the Creative Commons Attribution (CC BY) license (http:/ / creativecommons.org/licenses/by/4.0/). 